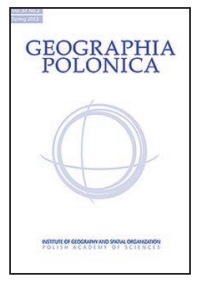

\title{
WHERE THE MEGHALAYAN MEETS THE ANTHROPOCENE: STRATIGRAPHIC SIGNALS OF HUMAN-ENVIRONMENTAL INTERACTIONS ON THE PERIPHERY OF INDIAN CIVILISATION
}

\author{
Paweł Prokop \\ Institute of Geography and Spatial Organization \\ Polish Academy of Sciences \\ Jana 22, 31-018 Kraków: Poland \\ e-mail: pawel@zg.pan.krakow.pl
}

\begin{abstract}
The aims of this study were to review human-environment interactions during the Meghalayan and to search for the stratigraphic boundary of a new epoch, informally termed the Anthropocene, as well as to determine whether the stratigraphic signals of human activity on the Meghalaya Plateau in Northeast India can be correlated globally. This plateau is the base of the Meghalayan Age that was determined from a speleothem in a cave located on it. Review indicates that study region developed on the periphery of ancient Indian civilisation, with stratigraphic signals of human activity being apparent in only the last few thousand years; that is, substantially later than the neighbouring ancient Indian civilisation. The stratigraphic signals are heterogeneous and diachronous, not only as a result of various human activities, but also in the effect of the diverse sensitivities of the environment to anthropogenic disturbances. A discrete and visible cultural layer that relates to the development of settlements and the production of new materials is still being formed and reworked. The only synchronous stratigraphic signal with a global range seems to be associated with the artificial radionuclide fallout from nuclear weapons testing, which covers a topsoil layer of up to tens of centimetres thick.
\end{abstract}

\section{Key words}

stratigraphy $\cdot$ Holocene $\cdot$ Anthropocene $\cdot$ Meghalaya $\cdot$ human impact

\section{Introduction}

Human-environment interactions exhibit great diversity, with many feedbacks and nonlinear processes, thresholds and time lags (An, 2012; Ruddiman, Ellis, Kaplan \& Fuller, 2015; Waters \&Zalasiewicz, 2018; Zalasiewicz et al., 2019b).
The effects of such interactions can be preserved in accumulating strata as lithostratigraphic (environmental and human-induced sediment transport and deposition, modification of terrain, deposition related to constructions, etc.), biostratigraphic (pollen grains spectra, extinctions and invasions of species) 
and chemostratigraphic (heavy metal tracers, isotopes, artificial radionuclides) signals (Zalasiewicz et al., 2019). Such markers provide a record of Earth's history, and can form the basis for its subdivision within the Geological Time Scale (GTS; Gradstein, Ogg, Schmitz, \& Ogg, 2012).

The units of geological time are defined with reference to their lower boundaries - their beginnings or 'bases' (Gradstein et al., 2012). Such boundaries are drawn using a Global Stratigraphic Section and Point (GSSP) or, before GSSP, can be defined by an agreed date, termed a Global Stratigraphic Standard Age (GSSA). For a GSSP, 'stratigraphic section' refers to a deposit (rock, sediment, glacier ice, speleothem) that developed an adequate thickness over time that is chosen as the representative (i.e. type) section, known as the 'stratotype', while 'point' refers to the location of the marker used to define the boundary within the stratotype. GSSP markers should ideally be complemented by a series of auxiliary stratigraphic sections that are globally synchronous. GSSPS must also have an exact location and height or depth, and must be accessible and have provisions for conservation and protection. Proposals for new GSSPs must be formally ratified by the International Union of Geological Sciences (IUGS).

The same criteria had to be met in the defining and subdivision of the Holocene Epoch, which is the epoch in which we live. The term 'Holocene' (meaning 'entirely recent') has been used for almost 150 years (Walker et al., 2009); however, it was only formally ratified by the IUGS in 2008 . While the Holocene refers to the current interglacial, it is also known for the expansion of humans, the development of agriculture, and the growing use of metals. Thus, even before the formal ratification of the Holocene as an epoch, it was being suggested that that epoch was over and that a new epoch, called the Anthropocene, had begun, its beginning distinguished by the start of significant human activity (Crutzen \& Stroemer, 2000; Crutzen, 2002).
Since then, 'Anthropocene', as an informal term, has become popular, being used among different scientific communities, including scholars in the humanities, as well as in the scientific literature, discussions and the public media (Fig. 1). Three scientific journals listed in the Journal Citation Report have the word 'Anthropocene' in their titles -, The Anthropocene (Elsevier), The Anthropocene Review (SAGE) and Elementa: Science of the Anthropocene (University of California Press). Simultaneously, since 2009 an Anthropocene Working Group (AWG) has been looking for scientific evidence for the basal Anthropocene boundary to support its ratification by the IUGS as an epoch in the GTS (Zalasiewicz et al., 2019). The problem of boundary demarcation was slightly complicated when, in 2018, the IUGS accepted a subdivision of the Holocene Epoch, the new units being the Greenlandian, the Northgrippian (both named after GSSPs located in Greenland) and the Meghalayan (the GSSP located in Meghalaya state in Northeast India) Ages, which correspond to the Early, Middle and Late Holocene, respectively (Walker et al., 2018). In effect, officially, we live in the Meghalayan Age of the Holocene Epoch, while the Anthropocene is used as an informal (i.e. not yet officially defined) geological unit.

The ratification of the Meghalayan Age drew attention to the small state that covers the hilly plateau located in Northeast India. This region lies at the junction of South Asia, East Asia and Southeast Asia, and has been throughout the ages one of the most diverse areas in Asia, in terms of human-environmental interactions (Ramakrishnan, 1992; Migoń \& Prokop, 2013; Prokop, 2014; Hazarika, 2017). The Meghalaya Plateau is the first barrier to northward-moving air masses from the Bay of Bengal to the Himalayas, and as such receives the highest amount of orographic rainfall in the world, concentrated in the summer monsoon season (Prokop \& Walanus, 2015). In contrast, the low retention capacity of its soils, due to the geological conditions in the area, results in water shortages during the dry season (Starkel \& Singh, 2004). 


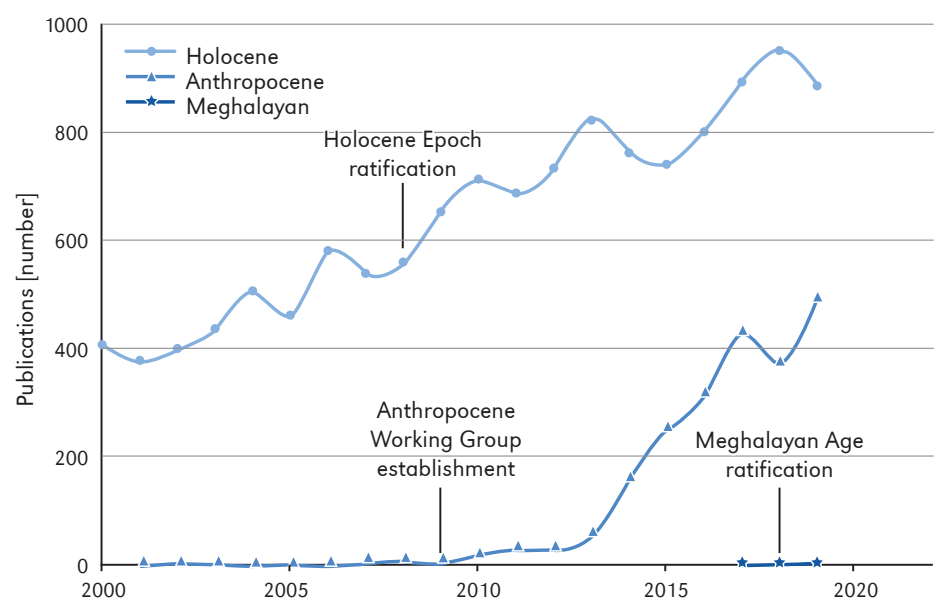

Figure 1. Publications in Web of Science with the topics Holocene, Anthropocene and Meghalayan from 2000 to 2019

The strong seasonality of the rainfall causes this region to be equally vulnerable to floods and droughts, representing a significant barrier to human activity. At the same time, the neighbouring lowlands, incorporating the Brahmaputra Valley and Bengal Plain, were corridors for early human dispersal between South and East Asia, which may explain the cultural diversity of the Austro-Asiatic and Sino-Tibetan populations that inhabit this area (Hazarika, 2017).

The main aim of the present study is to review the role of natural and human-induced factors in the transformation of the environment of the region where the Meghalayan GSSP is located. Assuming that, in the Anthropocene, humans impact on the Earth system at a global scale but their activities are heterogeneous in space and time, it is important to recognize the stratigraphic signals of this impact in areas that have been developing on the periphery of ancient civilisations.

More specifically, the objectives of the study are:

- (i) to review records of human-environment interactions during the Meghalayan, in contrast to the background Holocene;

- (ii) to investigate search for a definitive base for the Anthropocene as a potential geological unit; and
- (iii) to determine whether the effects of human-environmental interactions, in the form of biogeochemical stratigraphic signals on the Meghalaya Plateau, can be correlated globally.

\section{The Meghalayan Age versus the background of the Holocene Epoch in the context of human- -environmental interactions}

The Holocene is the shortest epoch in the GTS and, representing an interglacial, is relatively uniform in terms of climatic conditions. Thus, its formal subdivision was based on a natural, short-lived episode that has left traces in the proxy climatic record (i.e. changes in the stable oxygen isotope content in ice and speleothems). Two such proxy events were used for the global correlation of the Greenlandian/ Northgrippian and Northgrippian/Meghalayan boundaries (Walker et al., 2018).

The GSSP for the Greenlandian is the same used for the previously ratified basal Holocene in the NorthGRIP2 ice core, drilled in the central Greenland ice sheet $\left(75.10^{\circ} \mathrm{N}\right.$, $42.32^{\circ} \mathrm{W}$ ). This boundary corresponds to the first signs of climatic warming at the end of the Younger Dryas at 11,703 \pm 99 years b2k (before 2000 AD) (Walker et al., 2009). 
The basal Northgrippian was defined in the NorthGRIP1 Greenland ice core $\left(75.10^{\circ} \mathrm{N}\right.$, $42.32^{\circ} \mathrm{W}$ ), in which there was a clear signal of climate cooling at $8,236 \pm 47$ years b2k that reflects an outburst of water from glacial lakes pouring into the North Atlantic Ocean during the recession of the Laurentide Ice Sheet (Alley \& Ágústdóttir, 2005; Kleiven et al., 2008). These floods are believed to have disrupted the ocean-current conveyor belt, leading to global cooling.

The base of the Meghalayan is dated at 4,250 years b2k, and its GSSP is represented by a speleothem in the Mawmluh Cave $\left(25^{\circ} 15^{\prime} 44^{\prime \prime} \mathrm{N}, \quad 91^{\circ} 42^{\prime} 54^{\prime \prime} \mathrm{E}\right)$ in Meghalaya state, Northeast India (Fig. 2, 3). The 7-kmlong cave, situated on the southern edge of the Meghalaya Plateau, formed along the contact between a dolomite and sandstone of Eocene age (Breitenbach et al., 2015). The location of the cave on the elevated southern edge (1300 m a.s.l.) of the plateau, between the Bay of Bengal and the Himalayas and Tibetan Plateau, make this area sensitive to the different forcings that govern the monsoon system in Asia (Prokop \& Walanus, 2015; Huguet et al., 2018). About 2 km northeast of the cave is the town of Cherrapunji, one of the rainiest inhabited environments on Earth, with more than $11,000 \mathrm{~mm}$ of rainfall recorded annually. The oxygen isotope record from the speleothem correlates the 4.2 ka event with a markedly weakened Asian summer monsoon spanning 200 years (Berkelhammer et al., 2012). This event was reported to have occurred in many regions around the world, especially in the mid and low latitudes, and was generally characterised by dry and cool climatic conditions (Thompson et al., 2002; Mayewski et al., 2004; Booth et al., 2005). The Meghalayan has received particular attention because there is evidence that this natural climatic event had an impact on human societies across the globe. It played an important role in the collapse of three of the four major ancient civilizations - Old Kingdom of Egypt (Arz, Lamy, \& Pätzold, 2006; Pennington, Hamdan, Pears, \& Sameh, 2019),
Mesopotamia (Weiss, 2017) and India (Staubwasser, Sirocko, Grootes, \& Segl, 2003; Dixit, Hodell, \& Petrie, 2014), as well as disrupting the Chinese civilisation (Liu \& Feng, 2012; Li et al., 2018).

Despite a growing human impact on the Earth system during the Holocene, none of its subdivisions were defined on the basis of stratigraphic signals directly related to anthropogenic activities. The main reasons were that changes resulting from human activities, although long lasting and potentially datable, were usually gradual, heterogeneous in space and diachronous (Ruddimann, 2013; Edgeworth et al., 2015; Edgeworth, Ellis, Gibbard, Neal, \& Ellis, 2019; Fig. 4).

The first use of fire and the megafauna extinctions were local, or not evenly distributed on a global scale, and occurred in the Pleistocene (Barnosky, Koch, Feranec, Wing, \& Shabel 2004; Glikson, 2013). Whilst ceramics are datable and preserve well in the stratigraphic record, they first appeared in Africa and East Asia before the advent of agriculture, and early southwest Asian farming cultures did not produce ceramics (Wu et al., 2012; Lewis \& Maslin, 2015). Crop and livestock domestication had multiple independent origins between $\sim 11,000$ and 2000 years ago (Larson et al., 2014). In effect, the Neolithic agricultural revolution initiated a conversion of forest and woodland to farming land, prompting large-scale but also diachronous alterations to the Earth's surface (Kaplan et al., 2010; Ellis, 2011). The ancient centers of domestication do not overlap with the presently most productive agricultural areas (Diamond, 2002). The onset of agriculture may have resulted in a gradual rise in carbon dioxide $\left(\mathrm{CO}_{2}\right)$ after $\sim 7000$ years ago and methane after $\sim 5000$ years ago (Ruddiman, 2003; Fuller et al., 2011); however, evidence that human activity was responsible for the increase in these greenhouse gases is still being debated (Broecker \& Stocker, 2006; Singarayer, Valdes, Friedlingstein, Nelson, \& Beerling, 2011; Ruddiman et al., 2016). The onset of the Bronze Age 5000 years ago and the Iron Age $\sim 3000$ years ago also 

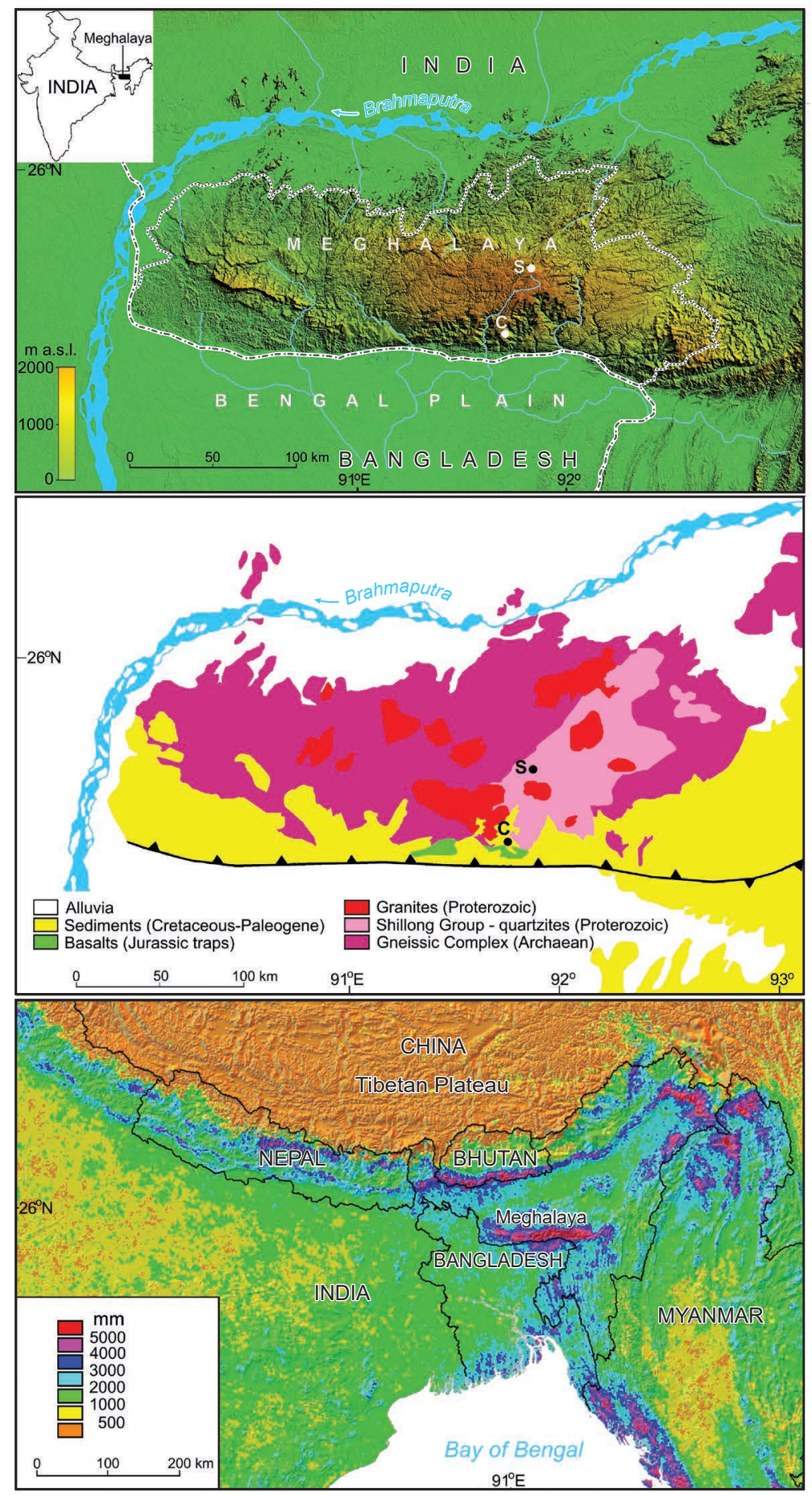

Figure 2. Relief map of Meghalaya Plateau (upper image), its geology (middle image compiled on the basis of Karunakaran, 1974 and Mazumder, 1986) and regional annual rainfall (lower image based on Tropical Rainfall Measuring Mission http://trmm.gfc.nasa.gov). C - Cherrapunji with Mawmluh Cave, $S$ - Shillong, dashed line - international border, dotted line - the Meghalaya State border 


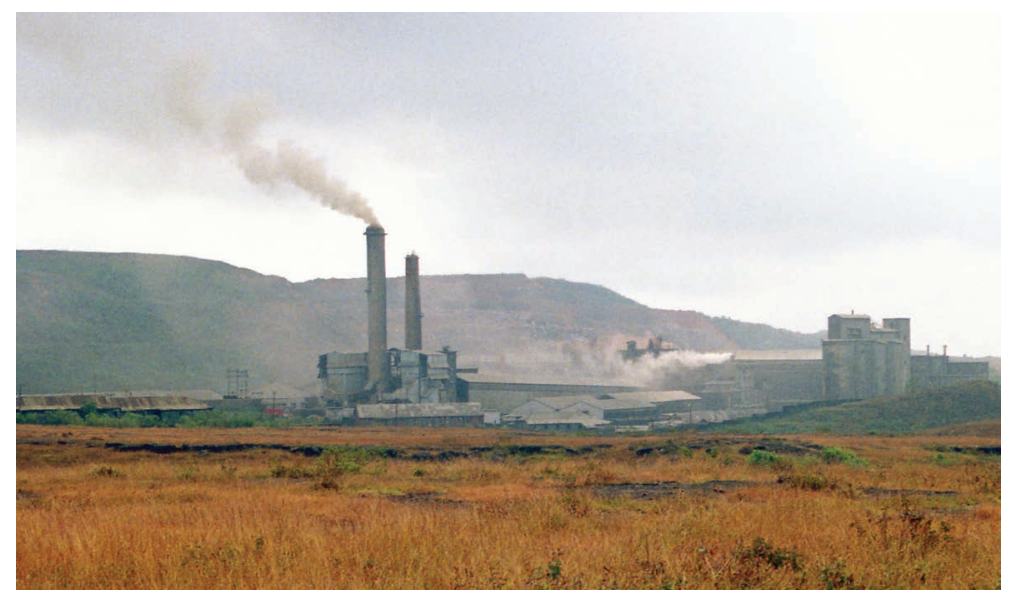

Figure 3. Where the Meghalayan meets the Anthropocene (Photo by P.Prokop). Mawmluh-Cherra Cement Factory (established in the early 1960s) extracting the limestone and dolomite bed where the Mawmluh Cave is located with the GSSP demarcating the Meghalayan boundary

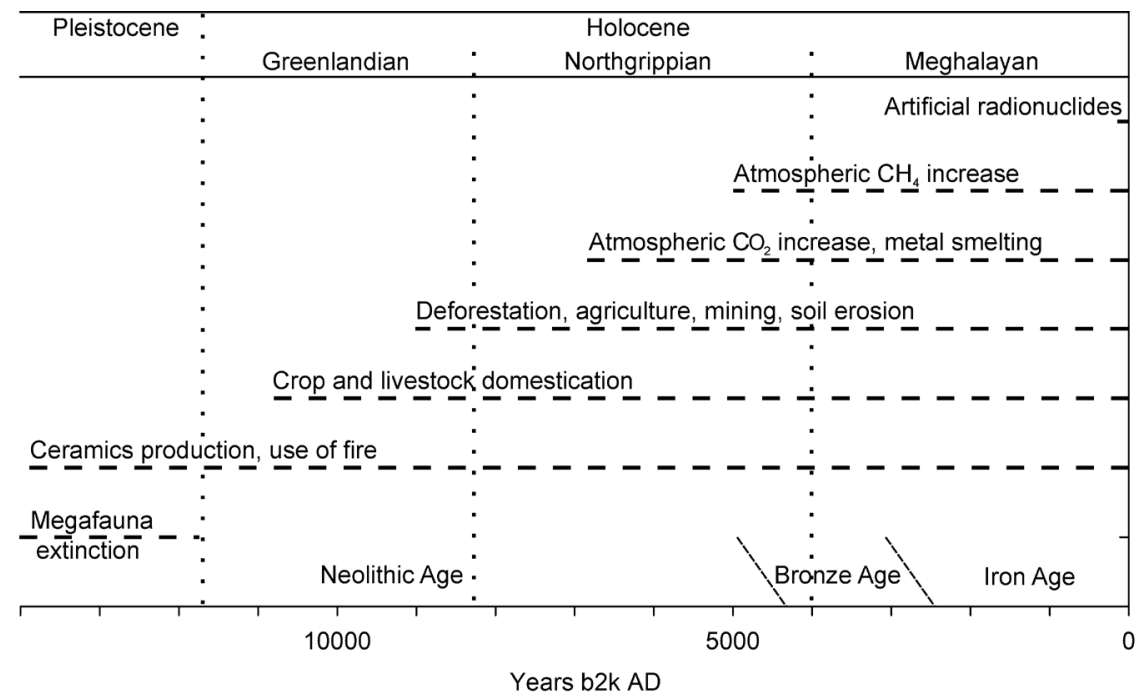

Figure 4. Long-term anthropogenic changes in the Earth system are diachronous and internally heterogeneous. Compiled on the basis of Ruddiman et al. (2015) concept: megafauna extinction (Barnosky et al., 2004), ceramics production and use of fire (Wu et al., 2012; Glikson, 2013), crop and livestock domestication (Diamond, 2002; Larson et al., 2014), deforestation (Kaplan et al., 2010; Ellis, 2011), mining and metal smelting (Hodges, 1992; Hook, 2000), atmospheric $\mathrm{CO}_{2}$ and $\mathrm{CH}_{4}$ increase (Ruddiman, 2003), artificial radionuclides (Zalasiewicz et al., 2015)

varied from region to region, before pollution and gases emission associated with metals smelting reaching globally-significant levels possible to record in remote areas such as Greenland ice sheet (Hong, Candelone,
Patterson, \& Boutron, 1996; Rudimann, Ellis, Kaplan, \& Fuller, 2015).

Therefore, it has been suggested that an Anthropocene Epoch is not required, given that some human influence is already 
contained within the definition of the Holocene (Gibbard \& Walker, 2014), and that 'Anthropocene' be used informally (Ruddiman et al., 2015; Ruddiman, 2018). Simultaneously, it has been argued that humans are currently the primary drivers of several global biogeochemical processes, including the hydrological and carbon cycles. Therefore, the effects of human activity can be identified in terms of the stratigraphic markers used for defining GSSPs and GSSAs (Zalasiewicz et al., 2015; Waters et al., 2018; Zalasiewicz et al. 2019a). The ratification of the Meghalayan, however, means that the potential base of the Anthropocene should be sought after 4,250 years b2k.

\section{The search for an Anthropocene boundary as a potential base for a new geological epoch}

Starting from the introduction of the term 'Anthropocene' in 2000, several approaches to determine its lower boundary, at a level above the base of the Meghalayan, have been presented. All of these have indicated that humans have changed not only Earth's climate, but the earth itself.

Certini and Scalenghe (2011) suggested that certain soils, derived from intensive cultivation during the last 2000 years, could be used as a marker for the proposed new geological epoch. The pedosphere is regarded as the best indicator of vegetation clearance, and a strong reflection of the growing impact of ancient civilisations over much of the Earth's surface. Although such soils are widespread, critics have pointed out that the suggested date for the expansion of anthropogenic soils is arbitrary (Gale \& Hoare, 2012). The spread of agriculture and the associated formation of cultivated soils is a diachronous process with no single determinable date.

Lewis and Maslin (2015) suggested the year 1610 for the base of the Anthropocene, terming this proposal the 'Orbis' (Latin for 'globe') hypothesis. This date was chosen because it is the lowest point within the around 100 years of decrease in atmospheric $\mathrm{CO}_{2}$, measured in Arctic ice cores.
The change in the atmosphere was possibly caused by the death of over 50 million indigenous inhabitants of the Americas after their exposure to diseases carried and spread by Europeans in the 15th and 16th centuries. The destruction of these indigenous populations caused a significant decline in farming, fire-burning and regeneration of forest that affected atmospheric $\mathrm{CO}_{2}$ levels.

The Industrial Revolution, with its onset in the late 1700s when fossil fuels began to be widely used, was also proposed as a base for the Anthropocene (Crutzen \& Stoermer, 2000; Crutzen, 2002). However, the initial spread of coal use was limited is space, having a relatively gradual increase in the 19th century, and thus it had an insignificant impact on global atmospheric $\mathrm{CO}_{2}$ concentrations at the time. Similarly, other coal-associated changes, including ash from fossil fuel burning and the resultant changes in lake sediments, increased slowly over many decades (Wolfe et al., 2013; Snowball, Hounslow, \& Nilsson, 2014).

In contrast to previous proposals, the AWG has preliminarily established an age for the base of the Anthropocene and the potential stratigraphic marker as being 16 July, 1945, when the first atomic bomb test took place in Alamogordo, New Mexico (Zalasiewicz et al., 2015). The working group chose this date because the isotopic products of bomb testing provide a globally distinctive marker horizon in soils, ice cores, lake sediments and oceans. Thus, they recommended that the base of the Anthropocene be defined by an agreed date (i.e. a GSSA, as a point in time in the human calendar) instead of being a GSSP. This proposal places the base of the Anthropocene close to the middle of the 20th century, coinciding with the Great Acceleration ( 1950) (Steffen, Crutzen, \& McNeill, 2007), which marks a major expansion in the human population, large changes in natural processes, widespread use of concrete for constructions, and the development of novel materials such as plastics (Waters \& Zalasiewicz, 2018; Zalasiewicz, Gabbott, \& Waters, 2019). 
As an alternative to the mentioned proposals, Lewis and Maslin (2015) suggested the peak in radionuclide fallout in 1964 as the base. This globally widespread marker, related to nuclear weapons testing, was detected in ${ }^{14} \mathrm{C}$ air measurements and captured in tree-rings and glacier ice. The annual tree-rings of a pine (Pinus sylvestris) from Niepołomice, near Kraków, Poland, which contain a ${ }^{14} \mathrm{C}$ peak in 1964, have been proposed as the GSSP. Potential auxiliary markers could include plutonium isotope ratios $\left({ }^{240} \mathrm{Pu} /{ }^{239} \mathrm{Pu}\right)$, and cesium $\left({ }^{137} \mathrm{Cs}\right)$ and iodine $\left({ }^{129} \mathrm{l}\right)$ isotopes, which are found in marine sediments and terrestrial soils.

\section{Stratigraphic signals of human- -environmental interactions on the Meghalaya Plateau}

The great diversity of the natural environment of the Meghalaya Plateau, combined with human activity, is reflected in various litho-, bio- and chemostratigraphic archives.
These records have different lengths and resolutions, as well as different levels of recognition to date (Fig. 5).

Speleothems occupy a special position among all these archives. Meghalaya, with its more than 1300 caves and almost $400 \mathrm{~km}$ of cave passages in a sedimentary rock complex, has great potential in terms of speleothem research (Gebauer, 2008). Its area hosts the longest cave (Liat Prah, $30 \mathrm{~km}$ ) and the deepest cave (Synrang Pamiang, $317 \mathrm{~m}$ ) in India. Thus, stalagmites represent the longest, high-resolution archives for describing both local and regional conditions of the natural environment (Kaushal et al., 2018). The uranium-thorium ( $\mathrm{U}^{230} \mathrm{Th}$ ) dating of several stalagmites, correlated with various geochemical proxies, such as stable carbon and oxygen isotopes, trace-element ratios (magnesium/calcium, uranium/calcium) and biomarkers, have been used to reconstruct monsoon rainfall intensity, air temperatures and vegetation cover for various periods between $33,788 \pm 269$ years BP (before present, where

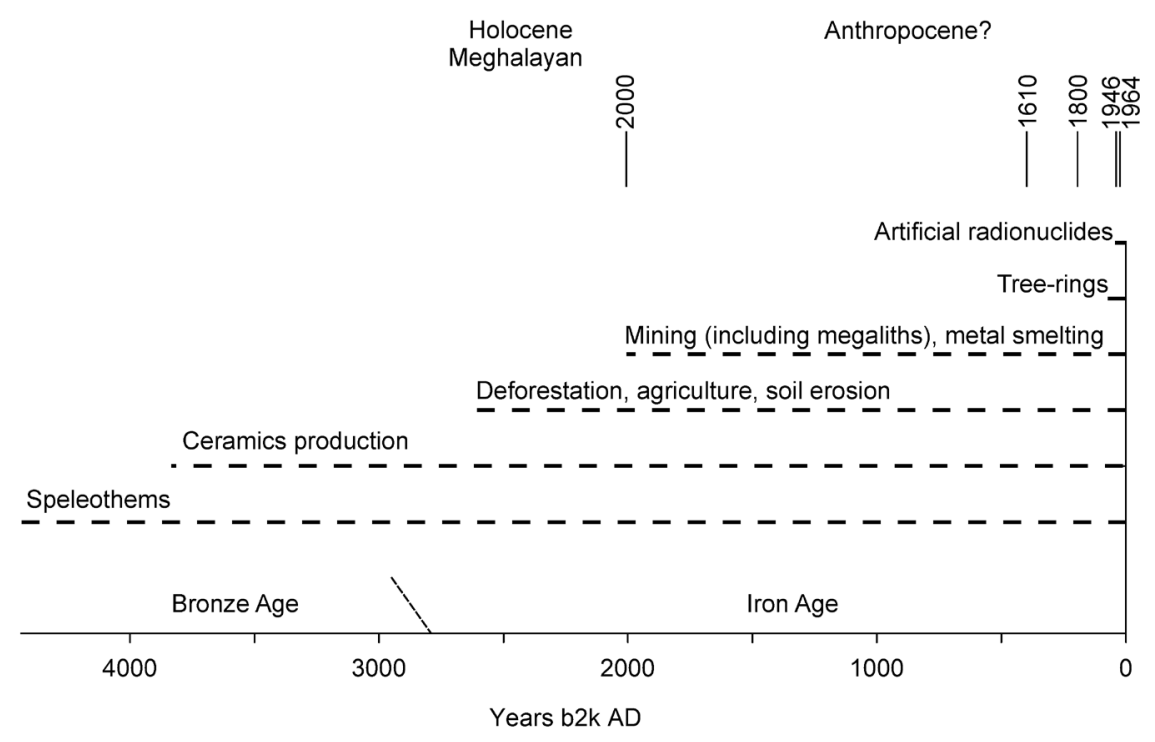

Figure 5. Stratigraphic archives of natural-human interactions in the Meghalaya Plateau during the Meghalayan. Proposed Anthropogenic boundaries are marked by years (see text). Complied on the basis: speleothems (Breitenbach, 2009, Berkelhammer et al., 2014; Lechleitner et al., 2017; Huguet et al., 2018), ceramics production (Mitri \& Neog, 2016), deforestation (Prokop \& Bhattacharyya, 2011), mining and metal smelting (Prokop \& Suliga, 2013), tree rings (Chaudhary \& Bhattacharyya, 2002), artificial radionuclides (Poręba \& Prokop, 2011) 
'present' is defined as 1950), the oldest date retrieved form from the speleothems in Meghalaya, and the present day (Dutt et al., 2015; Kaushal et al., 2018). Stalagmites from five caves have been analysed, including from the Mawmluh Cave, which contains the GSSP marking the base of the Meghalayan (Breitenbach, 2009; Berkelhammer et al., 2014; Lechleitner et al., 2017; Huguet et al., 2018; Ronay, Breitenbach, \& Oster, 2019). These have provided data mainly on the climatic context of human activity. Speleothem analysis have indicated greater rainfall than today between $3000 \mathrm{BC}$ and $400 \mathrm{AD}$ and large rainfall fluctuations, especially in the last 1600 years in Meghalaya (Breitenbach, 2009). More research is required however, to verify if some of the elemental concentrations (strontium, barium, uranium, copper, etc.) detected in speleothems can record the direct effects of any anthropogenic impact on the environment.

Dendrochronological data have been less explored in the region. A tree-ring analysis of Pinus kesiya (Royle ex Gordon), which grows on the Meghalaya Plateau near Shillong, has been performed (Chaudhary \& Bhattacharyya, 2002), which produced five chronologies, ranging from 80 to 142 years. A correlation of these tree-ring chronologies with the climate of Shillong has indicated that there has been no common climatic response to the growth of pines in this region. Longer or older dendrochronologies might be available from fossil trees or dead wood from building structures. Unfortunately, these tree-rings were not analysed for their ${ }^{14} \mathrm{C}$ radioisotope content and a record of discrete human impacts, such as nuclear weapons tests.

Sediments, in the context of humanenvironmental interactions, are complex in Meghalaya. In general, the spatiotemporal extent of the Quaternary sediments indicates that they are shallow at most of the studied sites, (Prokop \& Bhattacharyya, 2011b). Radiocarbon dating of these deposits suggests that they are mostly Holocene in age or, in rare cases, upper Pleistocene. This might be due to the extremely high rainfall in the area, and perhaps also intensive human activity, which accelerated soil and stream-bank erosion after deforestation, removing deposits from the hilly plateau.

The Meghalaya Plateau has the precipitation and temperatures sufficient to support forest growth, which is the climax vegetation in this region (Bor, 1942). However, grasses growing on degraded soils prevail at elevations above $1000 \mathrm{~m}$ a.s.l. Pollen and grain size analyses, supported by the radiocarbon dating of several colluvial, alluvial and lacustrine sedimentary profiles in the region, have provided records of the climatic conditions and the human impact during the Meghalayan (Prokop \& Bhattacharyya, 2011a). These show that some locations in the central part of the plateau were already occupied by open meadows around 2500 years BP ( 700 BC), and were close to subtropical forests, with trees such as Quercus, Betula, Carpinus, Myrica, Alnus, llex and Prunus being common elements. Around 900 years BP ( 1100 AD), the amount of Pinus pollen increased in all of the profiles, and there was an increased input of fine-grained mineral material into lacustrine sediments. These might indicate a progressive deforestation of some parts of the Meghalaya Plateau. Subsequently, over the last 500 years, this forest has been much degraded, as evidenced by the presence of a large amount of charcoal in coarsegrained colluvial deposits. Trees, except for members of the Arecaceae, have become rare or are absent. Likely both an intensification of agriculture and iron-ore extraction and processing in the conditions of high rainfall have been responsible for this deforestation and the resultant accelerated soil erosion (Soja \& Starkel, 2007; Prokop, 2016).

Generally, the estimated age of this deforestation and soil erosion is similar to the ages provided by archaeological artifacts, including ceramics. Relatively rare radiocarbon dates from the excavated sites have indicated that the Northeast Indian Neolithic complex appeared relatively late when compared to neighbouring regions, arriving between 2500 and 1500 BC (Hazarika, 
2017, 2019). The ceramics found at several sites in the central part of the Meghalaya Plateau are mostly handmade, burnt at low temperatures, and bear cord impressions, a common and characteristic feature of the Neolithic ceramics of Northeast India (Mitri, Kharmawphlang, \& Syiemlieh, 2015; Mitri \& Neog, 2016). Charcoal from a cultural layer and its associated ceramics, at a depth of $50 \mathrm{~cm}$, have indicated a radiocarbon age of $3,500 \pm 30$ years BP ( 1800 BC). Samples from two other cultural layers have given radiocarbon ages of $2,960 \pm 30$ years $B P$ to $1,640 \pm 30$ years BP ( $1200 \mathrm{BC}$ to $\sim 400 \mathrm{AD})$. However, palynological and archaeological data are too scarce to be able to use to draw firm conclusions from in terms of their relationships.

The age of deforestation and ceramics production also correlates with the local mining and processing of (titaniferous) iron ore from weathered granites in the central part of the Meghalaya Plateau (Cracroft, 1832; Prokop \& Suliga, 2013). The radiocarbon dating of charcoal, and the chemical, microstructural and phase composition of the iron ore and slag, indicate that the smelting of iron began as early as 2,040 \pm 80 years BP (353 BC-128 AD) and continued up to the middle of the 19th century (Hunter, 1879). Traces of the iron industry are still visible as washed sand with charcoal, clay tuyeres and slag in deposits from several centimetres to several metres thick. Large-scale metallurgical production, alongside agriculture was likely responsible for the deforestation of the central part of the plateau.

The mining and metallurgical tradition was accompanied by the erection of megalithic memorial monuments that bear similarities to other megalithic sites in India associated with the Copper-Bronze or Iron Ages (Gullapali, 2009). The beginnings of this tradition have not been dated, but megaliths were still being erected in the 19th century (Clarke, 1874). The studied area was known for the largest number of megaliths in the world, many of which have survived to this day (Fergusson, 1872). Currently, only the intensive quarrying of limestone (from at least the 18th century) and coal mining (from the 1840s) are being continued in the sedimentary complex of rocks covering the southern plateau, while the extraction of crystalline rocks for construction purposes is ongoing from the central and northern plateau (Lindsay, 1840; Oldham, 1854; Shankar, Boral, Pandey, \& Tripathi, 1993; Raczkowska, Bucała-Hrabia, \& Prokop, 2018). The stratigraphic record of mining includes the terrain modification associated with surface rock extraction and the redeposition of rocks and soils, along with changes in their chemical properties. Locally, such disturbances can reach tens of metres in thickness.

Human activity has led to an increase in spatial soil heterogeneity in the naturally diverse environment of Meghalaya. The removal of vegetation by humans accelerated erosion in the past, leading to three types of stratigraphic record of these activities in the soils (Starkel \& Singh, 2004; Prokop, Kruczkowska, Syiemlieh, \& Bucała-Hrabia, 2018; Raczkowska et al., 2018; Fig. 6). These include: 1) the complete removal of the soil cover; 2) the formation of an armoured stone layer (up to $15-20 \mathrm{~cm}$ thick) on the soil surface due to the selective erosion of fine soil particles; and 3) burying the old soil under a new soil layer (up to $\sim 1.5 \mathrm{~m}$ thick) as a result of erosion and transportation from the upper parts of slopes. The first two types occur within the sedimentary rock complex, where shallow soils have developed on sandstones that are resistant to weathering and on limestones that are susceptible to dissolution, both also being located in the range of extremely high rainfall. The third type dominates in deep soils developed over crystalline rocks, influenced by a lower annual rainfall of 1500$4000 \mathrm{~mm}$. The surface of this soil layer is still cultivated, and can contain a lot of charcoal from the burning of vegetation, which is used as a natural fertiliser. In addition, its physical and chemical properties, such as texture, $\mathrm{pH}$, cation exchange capacity, exchangeable aluminium, potassium, sodium, calcium and magnesium, and base saturation in relation 

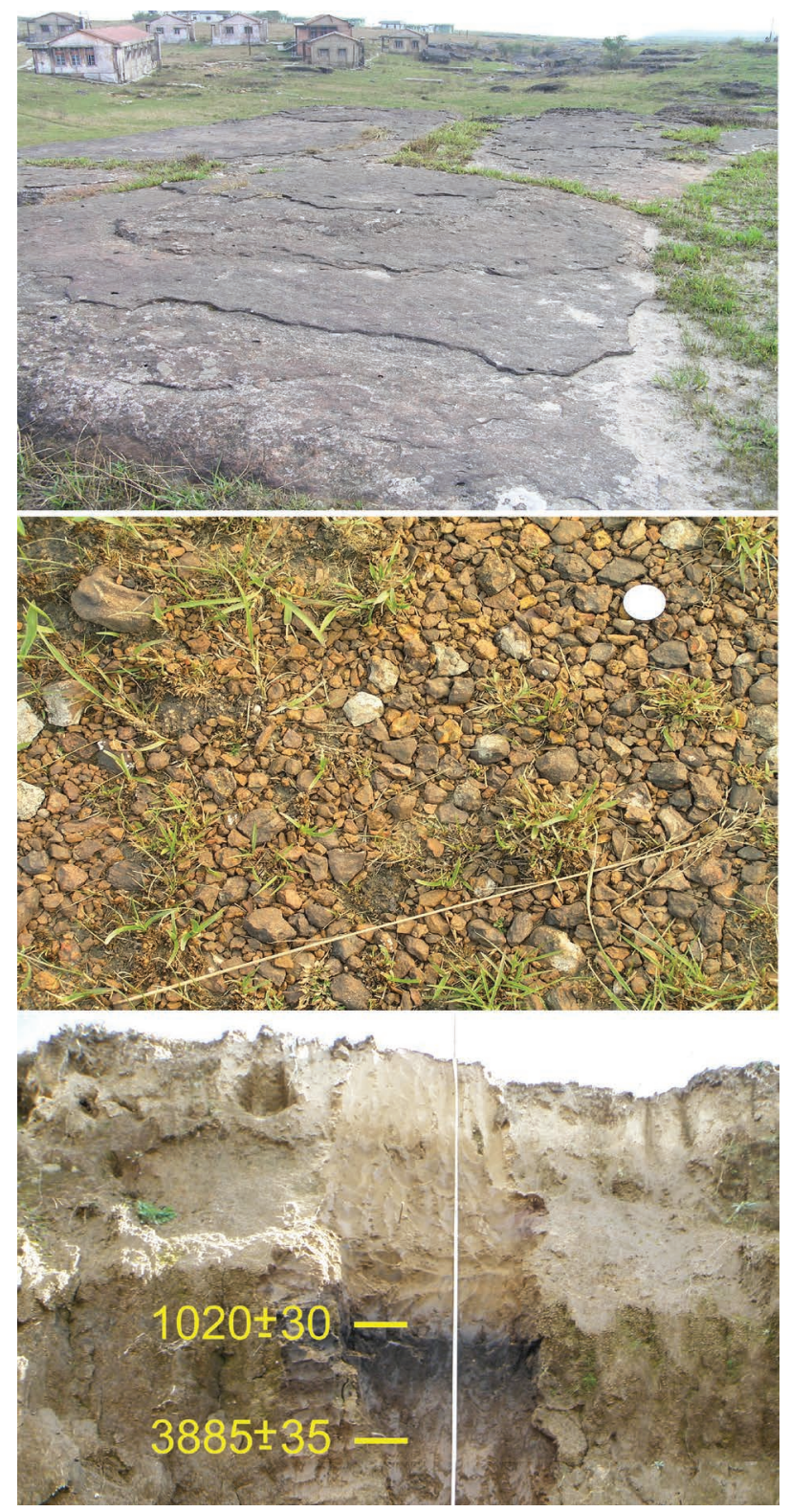

Figure 6. Three types of stratigraphic record of human activities in the soils of the Meghalaya Plateau (photos by P.Prokop). The complete removal of the soil cover (upper image) in effect of deforestation and high rainfall; the formation of an armoured stone layer on the soil surface due to the selective erosion of fine soil particles (middle image); burial of the old soil under the accumulation of a new soil layer as a result of erosion and transport (lower image with radiocarbon dates in years BP)

to natural forest areas have changed (Prokop et al., 2018).

Regardless of the degree of the physical and chemical soil property transformations by humans, all the soils of Meghalaya have been exposed to the radionuclide fallout associated with the nuclear weapons tests (Froehlich, 2004; Poręba \& Prokop, 2011). 
The concentrations of cesium $\left({ }^{137} \mathrm{Cs}\right)$ and lead $\left({ }^{210} \mathrm{~Pb}\right)$ radionuclides in the soil has been investigated to estimate the intensity of soil erosion. Two studies were conducted in the central part of the Plateau, near Shillong, that had an annual rainfall of $2400 \mathrm{~mm}$ (Poręba \& Prokop, 2011), and in the southern part, near Cherrapunji, with its annual rainfall of $11,000 \mathrm{~mm}$ (Froehlich, 2004).

To calculate the annual values of the ${ }^{137} \mathrm{Cs}$ fallout, a model by Sarmiento and Gwinn (1986) for predicting ${ }^{90} \mathrm{~S} r$ fallout was adapted, using monthly rainfall data from Shillong. The ratio between ${ }^{137} \mathrm{Cs}$ and ${ }^{90} \mathrm{Sr}$ is well known and, thus, it has been possible to use this model to estimate the annual ${ }^{137} \mathrm{Cs}$ fallout (Poręba \& Bluszcz, 2007). The total value of ${ }^{137} \mathrm{Cs}$ deposition, calculated using the mod$\mathrm{el}$, reached 1,100 Bq m${ }^{-2}$ (Fig. 7). This is close to the measured mean value of the ${ }^{137} \mathrm{Cs}$ reference inventory (undisturbed by human activity) in soil near Shillong, which was equal to $1,220 \pm 260 \mathrm{~Bq} \mathrm{~m}{ }^{-2}$. In addition, the calculated annual values of ${ }^{137} \mathrm{Cs}$ fallout have indicated that more than $52 \%$ of the ${ }^{137} \mathrm{Cs}$ deposition, for the years 1962-1965, occurred because of the high intensity of the nuclear weapons testing.
The amount of radionuclide fallout generally increases with increasing rainfall. Thus, the measured ${ }^{137} \mathrm{Cs}$ reference inventory in the soil near Cherrapunji was higher than that in Shillong, reaching 1,495 $\pm 39 \mathrm{~Bq} \mathrm{~m} \mathrm{~m}^{-2}$ (Froehlich, 2004). The measured reference inventory of ${ }^{210} \mathrm{~Pb}$ in the same soil was $4,605 \pm 55 \mathrm{~Bq} \mathrm{~m}^{-2}$.

At Shillong and Cherrapunji, the depth of the cesium in the soil was 25 and $35 \mathrm{~cm}$, respectively. Much of the vertical translocation of the radionuclides in these profiles can be related to organic matter production at the grassland surface, the chemical diffusion associated with rainfall, and the downward transportation via macropores in the skeletal topsoil profile.

Among all the stratigraphic signals, the one associated with processed, manufactured production and the use of new materials, such as concrete, brick and plastic, is directly, and the most, visible in Meghalaya (Fig. 8). Cheap and widely-available cement, produced from locally-extracted limestones and dolomites, has resulted in the almost complete disappearance of traditional materials, such as wood, in building construction. The emergence of this new cultural layer has been intensified by rapid population growth,

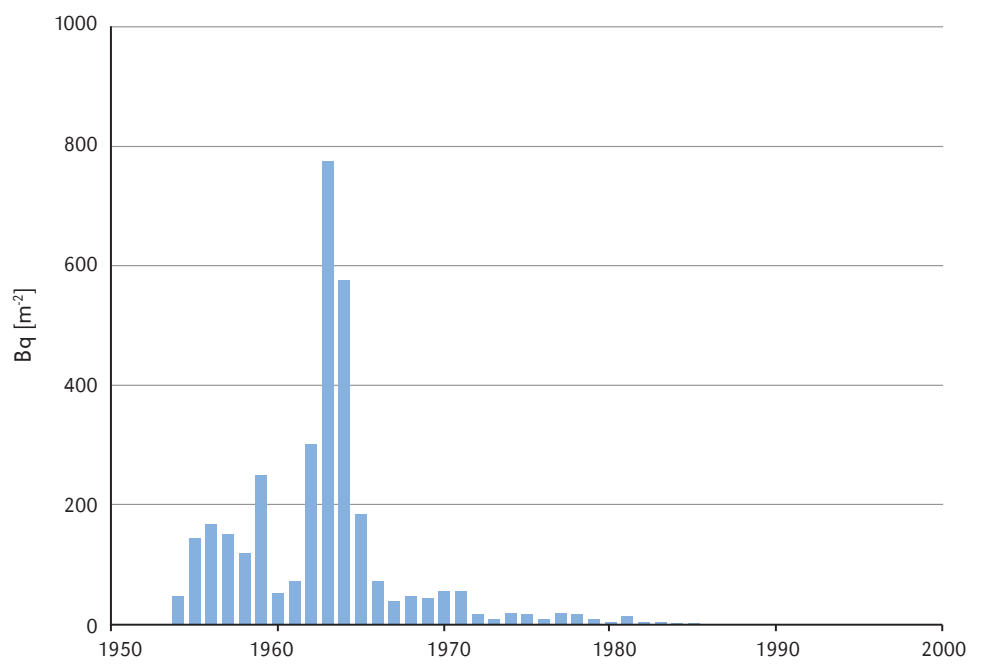

Figure 7. Annual ${ }^{137} \mathrm{Cs}$ fallout estimation from precipitation data at Shillong based on Sarmiento and Gwinn (1986) model 


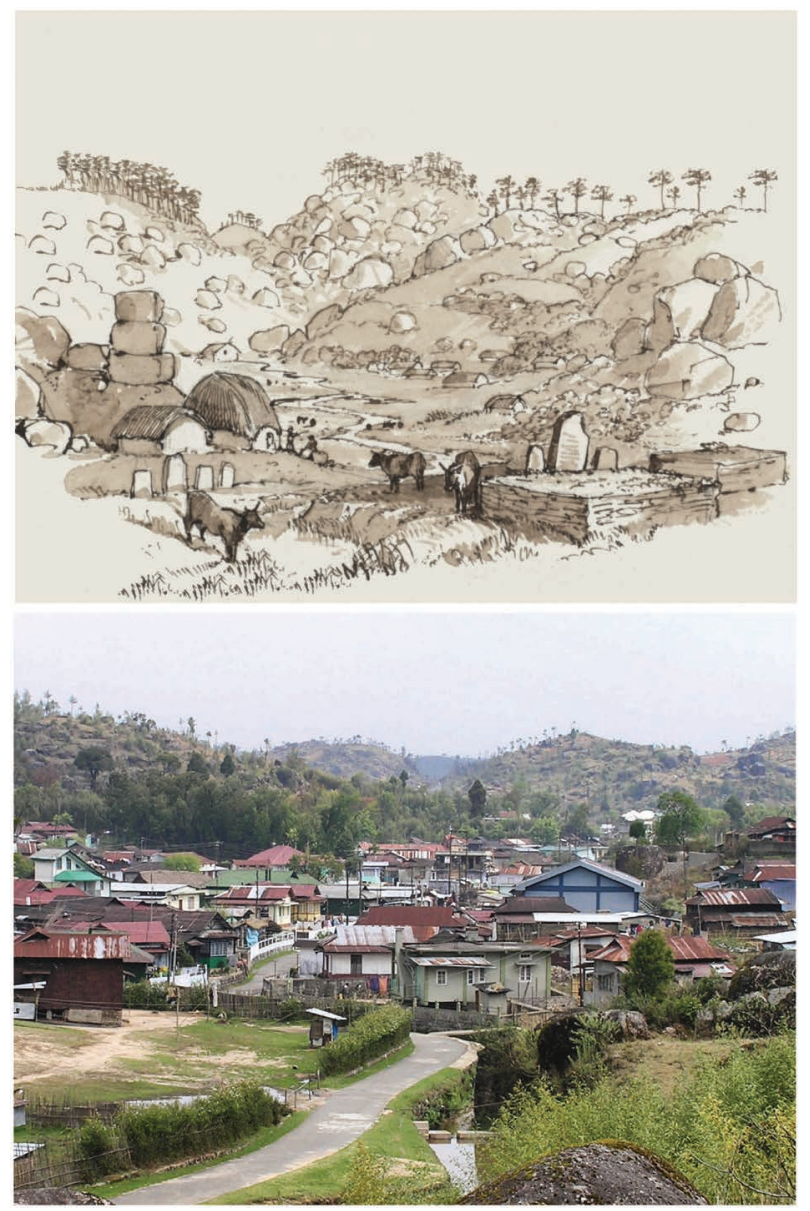

Figure 8. View of the Nongkrem village near Shillong in 1850 (upper image after sketch of Hooker, 1854) and 2015 (lower image photo by P. Prokop). Formation of the new anthropogenic layer. Expansion of settlement due to population increase is accompanied by conversion of buildings construction from wood to concrete and metal roofs, replacement of dirt roads with asphalt surfaces and stream embankments

the development of a settlement network, especially cities, and the lack of an organised system for municipal waste clearance. It is also an anthropogenic layer that is currently being formed, and constantly being reworked or redeposited in the form of destroying old buildings and erecting new ones, replacing dirt roads with hard surfaces, constructing river embankments, extracting minerals resources and back-filling mine workings, etc. Therefore, it is extremely heterogeneous in space, when compared to natural deposits, and is in the process of formation, similarly to what can be observed in other regions of the world (Ford, Price, Cooper, \&Waters, 2014; Waters \& Zalasiewicz, 2018).

\section{Conclusions}

This review indicates that, even in a peripherally-located area of Indian civilisation, there are numerous stratigraphic indicators of human activity. However, these only cover the last few thousand years of the Meghalayan Age, and so began later than in the neighbouring area of the ancient civilization 
of Northeast India. Over time, anthropogenic activity has been speeding up, operating at larger scales, and becoming more clearly detectable, from deforestation as a result of spreading agriculture, to the smelting of metals and the development of cities, and ultimately to the formation of a cultural layer made of new materials not previously found in the natural environment.

At this stage of our study, it is difficult to assess whether a record of human activity, can be reliably identified in speleothems, which mainly contain high-resolution archives of climatic change. The stratigraphic signals associated with ceramics and megalith artifacts, and deposits, including soils, mined minerals and processed metals, are heterogeneous and diachronous, not only as a result of various human activities, but also in terms of the broad sensitivity of the environment to anthropogenic disturbances. A highly-visible cultural layer related to the development of settlements and the production of new materials is still being formed and reworked. The only stratigraphic signal from the Meghalaya that can be correlated globally, is the evidence of the radionuclide fallout. This has been incorporated into a topsoil layer up to several tens of centimetres thick. It is also likely that a sudden increase in radiocarbon in the Earth's atmosphere due to nuclear testing has been captured by tree rings in the studied area, as has been detected globally.

Editors' note:

Unless otherwise stated, the sources of tables and figures are the authors', on the basis of their own research.

\section{References}

Alley, R.B., Ágústsdóttir, A.M. (2005). The 8k event: Cause and consequences of a major Holocene abrupt climate change. Quaternary Science Reviews, 24(10-11), 1123-1149. https://doi.org/10.1016/j.quascirev.2004.12.004

An, L. (2012). Modeling human decisions in coupled human and natural systems: Review of agent-based models. Ecological Modelling, 229, 25-36. https://doi.org/10.1016/j.ecolmodel.2011.07.010

Arz, H.W., Lamy, F., \& Pätzold, J. (2006). A pronounced dry event recorded around 4.2 ka in brine sediments from the northern Red Sea. Quaternary Research, 66(3), 432-441. https://doi.org/10.1016/j.yqres.2006.05.006

Barnosky, A.D., Koch, P.L., Feranec, R.S., Wing, S.L., Shabel, A.B. (2004). Assessing the causes of late Pleistocene extinctions on the continents. Science, 306(5693), 70-75. https://doi.org/10.1126/science.1101476

Berkelhammer, M., Sinha, A., Stott, L., Cheng, H., Pausata, F.S., Yoshimura, K. (2012). An abrupt shift in the Indian monsoon 4000 years ago. Geophysical Monographs Series, 198, 75-87. https://doi.org/10.1029/2012GM001207

Bor, N.L. (1942). Relict vegetation of Shillong Plateau-Assam. Indian Forest Records, 3, 152-195.

Breitenbach, S. (2009). Changes in monsoonal precipitation and atmospheric circulation during the Holocene reconstructed from stalagmites from Northeastern India. Ph.D. Thesis, University of Potsdam, Potsdam, Germany.

Breitenbach, S.F., Lechleitner, F.A., Meyer, H., Diengdoh, G., Mattey, D., \& Marwan, N. (2015). Cave ventilation and rainfall signals in dripwater in a monsoonal setting - a monitoring study from NE India. Chemical Geology, 402, 111-124. https://doi/org/10.1016/j.chemgeo.2015.03.011

Broecker, W.S., Stocker, T.F. (2006). The Holocene $\mathrm{CO}_{2}$ rise: Anthropogenic or natural? Eos. Earth \& Space Science News, 87(3), 27-27. https://doi.org/10.1029/2006EO030002 
Booth, R.K., Jackson, S.T., Forman, S.L., Kutzbach, J.E., Bettis lii, E.A., Kreigs, J., Wright, D.K. (2005). A severe centennial-scale drought in midcontinental North America 4200 years ago and apparent global linkages. The Holocene, 15(3), 321-328. https://doi.org/10.1191/0959683605hl825ft

Certini, G., Scalenghe, R. (2011). Anthropogenic soils are the golden spikes for the Anthropocene. The Holocene, 21(8), 1269-1274. https://doi.org/10.1177/0959683611408454

Chaudhary, V., Bhattacharyya, A. (2002). Suitability of Pinus kesiya in Shillong, Meghalaya for tree-ring analyses. Current Science, 83(8), 1010-1015.

Clarke, C.B. (1874). The Stone Monuments of the Khasi Hills. The Journal of the Anthropological Institute of Great Britain and Ireland, 3, 481-493.

Cracroft, W. (1832). Smelting of iron in the Kasya Hills. Journal Asiatic Society of Bengal, 1, 150-151.

Crutzen, P.J. (2002). Geology of mankind. Nature 415(6867), 23.

Crutzen, P.J., Stoermer, E.F. (2000). The "Anthropocene". Global Change Newsletter, 41, 17-18.

Diamond, J. (2002). Evolution, consequences and future of plant and animal domestication. Nature, 418(6898), 700-707. https://doi.org/10.1038/nature01019

Dixit, Y., Hodell, D.A., Petrie, C.A. (2014). Abrupt weakening of the summer monsoon in northwest India 4100 yr ago. Geology, 42(4), 339-342. https://doi.org/10.1130/G35236.1

Dutt, S., Gupta, A K., Clemens, S.C., Cheng, H., Singh, R.K., Kathayat, G., \& Edwards, R.L. (2015). Abrupt changes in Indian summer monsoon strength during 33,800 to 5500 years BP. Geophysical Research Letters, 42(13), 5526-5532. https://doi.org/10.1002/2015GL064015

Edgeworth, M., deB Richter, D., Waters, C., Haff, P., Neal, C., Price, S.J. (2015). Diachronous beginnings of the Anthropocene: The lower bounding surface of anthropogenic deposits. The Anthropocene Review, 2(1), 33-58. https://doi.org/10.1177/2053019614565394

Edgeworth, M., Ellis, E.C., Gibbard, P., Neal, C., Ellis, M. (2019). The chronostratigraphic method is unsuitable for determining the start of the Anthropocene. Progress in Physical Geography: Earth and Environment, 43(3), 334-344. https://doi.org/10.1177/0309133319831673

Ellis, E.C. (2011). Anthropogenic transformation of the terrestrial biosphere. Philosophical Transactions of the Royal Society A: Mathematical, Physical and Engineering Sciences, 369(1938), 1010-1035. https://doi.org/10.1098/rsta.2010.0331

Fergusson, J. (1872). Rude stone monuments in all countries: their age and uses. London: J. Murray.

Ford, J.R., Price, S.J., Cooper, A.H., Waters, C.N. (2014). An assessment of lithostratigraphy for anthropogenic deposits. Geological Society, London, Special Publications, 395(1), 55-89. http://dx.doi.org/10.1144/SP395.12

Froehlich, W. (2004). Soil erosion, suspended sediment sources and deposition in the Maw-Ki-Syiem drainage basin, Cherrapunji, northeastern India. IAHS Publication, 288, 138-146.

Fuller, D.Q., Van Etten, J., Manning, K., Castillo, C., Kingwell-Banham, E., Weisskopf, A., ... Hijmans, R.J. (2011). The contribution of rice agriculture and livestock pastoralism to prehistoric methane levels: An archaeological assessment. The Holocene, 21(5), 743-759.

https://doi.org/10.1177/0959683611398052

Gale, S.J., Hoare, P.G. (2012). The stratigraphic status of the Anthropocene. The Holocene, 22(12), 1491-1494. https://doi.org/10.1177/0959683612449764

Gebauer, H.D. (2008). Resources on the speleology of Meghalaya state, India. Part 1: overview. Berliner Höhlenkundliche Berichte, 33, 152.

Gibbard, P.L., Walker, M.J.C. (2014). The term 'Anthropocene'in the context of formal geological classification. Geological Society, London, Special Publications, 395(1), 29-37. https://doi.org/10.1144/SP395.1

Glikson, A. (2013). Fire and human evolution: the deep-time blueprints of the Anthropocene. Anthropocene, 3, 89-92. https://doi.org/10.1016/j.ancene.2014.02.002

Gradstein, F.M., Ogg, J.G., Schmitz, M., Ogg, G. (Eds.). (2012). The geologic time scale 2012. Elsevier. 
Gullapalli, P. (2009). Early metal in South India: copper and iron in megalithic contexts. Journal of World Prehistory, 22(4), 439-459. https://doi.org/10.1007/s10963-009-9028-0

Hazarika, M. (2017). Prehistory and archaeology of northeast India: multidisciplinary investigation in an archaeological terra incognita. Oxford University Press. https://doi.org/10.1093/oso/9780199474660.001.0001

Hazarika, M. (2019). Neolithic pottery of Eastern Himalaya and Northeast India. Development of Neolithic Cultures and diversity of pottery, Amsadong Site Research Series, Vol. 3, Seoul, South Korea, pp. 79-108

Hodges, H. (1992). Technology in the ancient world. New York: Barnes \& Noble Publishing.

Hong, S., Candelone, J.P., Patterson, C.C., Boutron, C.F. (1996). History of ancient copper smelting pollution during Roman and medieval times recorded in Greenland ice. Science, 272(5259), 246-249. https://doi.org/10.1126/science.272.5259.246

Hooke, R.L. (2000). On the history of humans as geomorphic agents. Geology, 28(9), 843-846.

Hooker, J.D. (1854).Himalayan Journals: Notes of a naturalist in Bengal, the Sikkim and Nepal Himalayas, the Khasia Mountains. In two volumes. London: J. Murray.

Huguet, C., Routh, J., Fietz, S., Lone, M.A., Kalpana, M.S., Ghosh, P., ... Rangarajan, R. (2018). Temperature and monsoon tango in a tropical stalagmite: last glacial-interglacial climate dynamics. Scientific Reports, 8(1), 5386. https://doi.org/10.1038/s41598-018-23606-w

Hunter, W.W. (1879). A statistical account of Assam (Vol. 2). Trübner \& Company.

Kaplan, J.O., Krumhardt, K.M., Ellis, E.C., Ruddiman, W.F., Lemmen, C., \& Goldewijk, K.K. (2011). Holocene carbon emissions as a result of anthropogenic land cover change. The Holocene, 21(5), 775-791. https://doi.org/10.1177/0959683610386983

Karunakaran, C. (1974). Geology and mineral resources of the states of India. Part IV-Arunachal Pradesh, Assam, Manipur, Meghalaya, Mizoram, Nagaland and Tripura. Geologial Survey of India Miscellaneous Publication, 30(4), 93-101.

Kaushal, N., Breitenbach, S.F., Lechleitner, F.A., Sinha, A., Tewari, V.C., Ahmad, S.M., ... Henderson, G.M. (2018). The indian summer monsoon from a speleothem $\delta^{18}$ O perspective-A Review. Quaternary, 1(3), 29. https://doi.org/10.3390/quat1030029

Kleiven, H.K.F., Kissel, C., Laj, C., Ninnemann, U.S., Richter, T.O., Cortijo, E. (2008). Reduced North Atlantic deep water coeval with the glacial Lake Agassiz freshwater outburst. Science, 319(5859), 60-64. https://10.1126/science.1148924

Larson, G., Piperno, D.R., Allaby, R.G., Purugganan, M.D., Andersson, L., Arroyo-Kalin, M., ... Doust, A.N. (2014). Current perspectives and the future of domestication studies. Proceedings of the National Academy of Sciences, 111(17), 6139-6146. https://doi.org/10.1073/pnas.1323964111

Lechleitner, F.A., Breitenbach, S.F., Cheng, H., Plessen, B., Rehfeld, K., Goswami, B., ... Haug, G. (2017). Climatic and in-cave influences on $\delta^{18} \mathrm{O}$ and $\delta^{13} \mathrm{C}$ in a stalagmite from northeastern India through the last deglaciation. Quaternary Research, 88(3), 458-471. https://doi.org/10.1017/qua.2017.72

Lewis, S.L., Maslin, M.A. (2015). Defining the anthropocene. Nature, 519(7542), 171-180. https://doi.org/10.1038/nature14258

Li, C.H., Li, Y.X., Zheng, Y.F., Yu, S.Y., Tang, L.Y., Li, B.B., Cui, Q.Y. (2018). A high-resolution pollen record from East China reveals large climate variability near the Northgrippian-Meghalayan boundary (around 4200 years ago) exerted societal influence. Palaeogeography, Palaeoclimatology, Palaeoecology, 512, 156-165. https://doi.org/10.1016/j.palaeo.2018.07.031

Lindsay, R. Lord, (1840). Lives of the Lindsays, or a memoir of the houses of Crawford and Balcarres to which are added, extracts from the official correspondence of Alex., Sixth Earl of Balcarres, during the Maroon War; Together with personal narratives by his brothers, the Hon. Robert, Colin, James, John, and Hugh Lindsay, 4 vol., Privately printed, Wigan. 
Liu, F., Feng, Z. (2012). A dramatic climatic transition at 4000 cal. yr BP and its cultural responses in Chinese cultural domains. The Holocene, 22(10), 1181-1197. https://doi.org/10.1177/0959683612441839

Mazumder, S.K. (1986). The Precambrian framework of part of the Khasi Hills, Meghalaya. Records of the Geological Survey of India, 117(2).

Mayewski, P.A., Rohling, E.E., Stager, J.C., Karlén, W., Maasch, K.A., Meeker, L.D., ... Lee-Thorp, J. (2004). Holocene climate variability. Quaternary Research, 62(3), 243-255.

https://doi.org/https://doi.org/10.1016/j.yqres.2004.07.001

Migoń, P., Prokop, P. (2013). Landforms and landscape evolution in the Mylliem Granite Area, Meghalaya Plateau, Northeast India. Singapore Journal of Tropical Geography, 34(2), 206-228. https://doi.org/10.1111/sjtg.12025

Mitri, M., Kharmawphlang, D., \& Syiemlieh, H. (2015). A preliminary report on the excavation of the Neolithic site at Law-Nongthroh (SohpetBneng Hill), Khasi Hills, Meghalaya. Man and Environment, 40(1), 33-42.

Mitri, M., Neog, D. (2016). Preliminary report on the excavations of Neolithic sites from Khasi Hills Meghalaya. Ancient Asia, 7, 1-17. http://dx.doi.org/10.5334/aa.119

Oldham, T. (1854). Geological structure of part of the Khasi Hills with observations on the meteorology and ethnology of that district. Calcutta: Bengal Military Orphan Press.

Pennington, B.T., Hamdan, M.A., Pears, B.R., Sameh, H.I. (2019). Aridification of the Egyptian Sahara 5000-4000 cal BP revealed from x-ray fluorescence analysis of Nile Delta sediments at Kom alAhmer/Kom Wasit. Quaternary International, 514, 108-118. https://doi.org/10.1016/j.quaint.2019.01.015

Poręba, G., Bluszcz, A. (2007). Determination of the initial 137Cs fallout on the areas contaminated by Chernobyl fallout. Geochronometria, 26(1), 35-38. https://doi.org/10.2478/v10003-007-0009-y

Poręba, G., Prokop, P. (2011). Estimation of soil erosion on cultivated fields on the hilly Meghalaya Plateau, North-East India. Geochronometria, 38(1), 77-84. https://doi.org/10.2478/s13386-011-0008-7

Prokop, P. (2014). The Meghalaya Plateau: landscapes in the abode of the clouds. In V.S. Kale (Ed), Landscapes and landforms of India (pp. 173-180). Dordrecht: Springer. https://doi.org/10.1007/978-94-017-8029-2_17

Prokop, P. (2016). Land use and land cover changes in the area with the highest rainfall in the world (Meghalaya Plateau, India): Causes and implications. In Environmental geography of South Asia (pp. 143-159). Springer, Tokyo. https://doi.org/0.1007/978-4-431-55741-8_9

Prokop, P., Bhattacharyya, A. (2011a). Environmental response to human impact on the Meghalaya Plateau (NE India) during the last 2500 yrs BP. International Association of Geomorphologists Regional Conference Abstract Volume, Ethiopia, 18-22 February, p. 125.

Prokop, P., Bhattacharyya, A. (2011b). Reconnaissance of quaternary sediments from Khasi Hills, Meghalaya. Journal of the Geological Society of India, 78(3), 258-262. https://doi.org/10.1007/s12594-011-0084-6

Prokop, P., Kruczkowska, B., Syiemlieh, H.J., Bucała-Hrabia, A. (2018). Impact of topography and sedentary swidden cultivation on soils in the hilly uplands of North-East India. Land Degradation \& Development, 29(8), 2760-2770. https://doi.org/10.1002/Idr.3018

Prokop, P., Suliga, I. (2013). Two thousand years of iron smelting in the Khasi Hills, Meghalaya, North East India. Current Science, 761-768.

Prokop, P., Walanus, A. (2015). Variation in the orographic extreme rain events over the Meghalaya Hills in northeast India in the two halves of the twentieth century. Theoretical and Applied Climatology, 121(1-2), 389-399. https://doi.org/10.1007/s00704-014-1224-x

Ramakrishnan, P.S. (1992). Shifting agriculture and sustainable development: an interdisciplinary study from north-eastern India. Parthenon Publications, Carnforth, UK. 
Rączkowska, Z., Bucała-Hrabia, A., Prokop, P. (2018). Geomorphological and sedimentological indicators of land degradation (Meghalaya Plateau, NE India). Land Degradation \& Development, 29(8), 2746-2759.

Ronay, E.R., Breitenbach, S.F., Oster, J.L. (2019). Sensitivity of speleothem records in the Indian Summer Monsoon region to dry season infiltration. Scientific Reports, 9(1), 1-10. https://doi.org/10.1038/s41598-019-41630-2

Ruddiman, W.F. (2003). The anthropogenic greenhouse era began thousands of years ago. Climatic Change, 61(3), 261-293.

Ruddiman, W.F. (2013). The anthropocene. Annual Review of Earth and Planetary Sciences, 41, 45-68. https://doi.org/10.1146/annurev-earth-050212-123944

Ruddiman, W.F. (2018). Three flaws in defining a formal 'Anthropocene'. Progress in Physical Geography: Earth and Environment, 42(4), 451-461. https://doi.org/10.1177/0309133318783142

Ruddiman, W.F., Fuller, D.Q., Kutzbach, J.E., Tzedakis, P.C., Kaplan, J.O., Ellis, E.C., ... Lemmen, C. (2016). Late Holocene climate: Natural or anthropogenic?. Reviews of Geophysics, 54(1), 93-118. https://doi.org/10.1002/2015RG000503

Ruddiman, W.F., Ellis, E.C., Kaplan, J.O., Fuller, D.Q. (2015). Defining the epoch we live in. Science, 348(6230), 38-39. https://doi.org/10.1126/science.aaa7297

Sarmiento, J.L., Gwinn, E. (1986). Strontium 90 fallout prediction. Journal of Geophysical Research: Oceans, 91(C6), 7631-7646.

Shankar, U., Boral, L., Pandey, H.N., Tripathi, R.S. (1993). Degradation of land due to coal mining and its natural recovery pattern. Current Science, 680-687.

Singarayer, J.S., Valdes, P.J., Friedlingstein, P., Nelson, S., Beerling, D.J. (2011). Late Holocene methane rise caused by orbitally controlled increase in tropical sources. Nature, 470(7332), 82-85. https://doi.org/10.1038/nature09739

Snowball, I., Hounslow, M.W., Nilsson, A. (2014). Geomagnetic and mineral magnetic characterization of the Anthropocene. Geological Society, London, Special Publications, 395(1), 119-141. https://doi.org/10.1144/SP395.13

Soja, R., \& Starkel, L. (2007). Extreme rainfalls in Eastern Himalaya and southern slope of Meghalaya Plateau and their geomorphologic impacts. Geomorphology, 84(3-4), 170-180. https://doi.org/10.1016/j.geomorph.2006.01.040

Starkel, L., Singh, S. (Eds.) (2004). Rainfall, runoff and soil erosion in the globally extreme humid area, Cherrapunji region, India. In Prace Geograficzne, 191. Warsaw: Institute of Geography and Spatial Organization.

Staubwasser, M., Sirocko, F., Grootes, P.M., Segl, M. (2003). Climate change at the 4.2 ka BP termination of the Indus valley civilization and Holocene south Asian monsoon variability. Geophysical Research Letters, 30(8). https://doi.org/10.1029/2002GL016822

Steffen, W., Crutzen, P.J., McNeill, J.R. (2007). The Anthropocene: are humans now overwhelming the great forces of nature. Ambio, 36(8), 614-621.

Thompson, L.G., Mosley-Thompson, E., Davis, M.E., Henderson, K.A., Brecher, H.H., Zagorodnov, V.S., ... Beer, J. (2002). Kilimanjaro ice core records: evidence of Holocene climate change in tropical Africa. Science, 298(5593), 589-593. https://doi.org/10.1126/science.1073198

Waters, C.N., Zalasiewicz, J. (2018). Concrete: the most abundant novel rock type of the Anthropocene. In D.A. Dellasala, M.I. Goldstein (eds.), Encyclopedia of the Anthropocene, 1, (pp. 75-85). Elsevier.

Waters, C.N., Zalasiewicz, J., Summerhayes, C., Fairchild, I.J., Rose, N.L., Loader, N.J., ... Williams, M. (2018). Global Boundary Stratotype Section and Point (GSSP) for the Anthropocene Series: Where and how to look for potential candidates. Earth-Science Reviews, 178, 379-429.

https://doi.org/10.1016/j.earscirev.2017.12.016 
Walker, M., Head, M.J., Berkelhammer, M., Björck, S., Cheng, H., Cwynar, L., ... Newnham, R. (2018). Formal ratification of the subdivision of the Holocene Series/Epoch (Quaternary System/Period): two new Global Boundary Stratotype Sections and Points (GSSPs) and three new stages/subseries. Episodes,41(4), 213-223. https://doi.org/10.18814/epiiugs/2018/018016

Walker, M., Johnsen, S., Rasmussen, S.O., Popp, T., Steffensen, J.P., Gibbard, P., ... Cwynar, L.C. (2009). Formal definition and dating of the GSSP (Global Stratotype Section and Point) for the base of the Holocene using the Greenland NGRIP ice core, and selected auxiliary records. Journal of Quaternary Science, 24(1), 3-17. https://doi.org/10.1002/jqs.1227

Weiss, H. (2017). 4.2 ka BP Megadrought and the Akkadian Collapse. Megadrought and Collapse: from early agriculture to Angkor. In Weiss, H, (Ed.) Oxford University Press, Oxford, 93-160.

Wolfe, A.P., Hobbs, W.O., Birks, H.H., Briner, J.P., Holmgren, S.U., Ingólfsson, Ó., ... Vinebrooke, R.D. (2013). Stratigraphic expressions of the Holocene-Anthropocene transition revealed in sediments from remote lakes. Earth-Science Reviews, 116, 17-34. https://doi.org/10.1016/j.earscirev.2012.11.001

Wu, X., Zhang, C., Goldberg, P., Cohen, D., Pan, Y., Arpin, T., Bar-Yosef, O. (2012). Early pottery at 20,000 years ago in Xianrendong Cave, China. Science, 336(6089), 1696-1700. https://doi.org/10.1126/science.1218643

Zalasiewicz, J., Gabbott, S., Waters, C.N. (2019). Plastic waste: How plastics have become part of the Earth's geological cycle. In Waste (pp. 443-452). Academic Press.

Zalasiewicz, J., Waters, C.N., Head, M.J., Poirier, C., Summerhayes, C.P., Leinfelder, R., ... McNeill, J.R. (2019a). A formal Anthropocene is compatible with but distinct from its diachronous anthropogenic counterparts: a response to WF Ruddiman's 'three flaws in defining a formal Anthropocene'. Progress in Physical Geography: Earth and Environment, 43(3), 319-333. https://doi.org/10.1177/0309133319832607

Zalasiewicz, J., Waters, C.N., Williams, M., Barnosky, A.D., Cearreta, A., Crutzen, P., ... Haff, P.K. (2015). When did the Anthropocene begin? A mid-twentieth century boundary level is stratigraphically optimal. Quaternary International, 383, 196-203. http://dx.doi.org/10.1016/j.quaint.2014.11.045

Zalasiewicz, J., Waters, C.N., Williams, M., Summerhayes, C.P., Head, M.J., Leinfelder, R., ... Wing, S. (2019b). History and development of the Anthropocene as a stratigraphic concept. In The Anthropocene as a geological time unit: A guide to the scientific evidence and current debate, 1. (pp. 1-40), UK: Cambridge University Press. https://doi.org/10.1017/9781108621359.001 
